\title{
Family as One of the Most Important Factors in a Child's Upbringing
}

\author{
Jaroslav Oberuč - Ladislav Zapletal* \\ Received: February 1, 2017; received in revised form: May 15, 2017; \\ accepted: May 17, 2017
}

\begin{abstract}
:
Introduction: The development of a child takes place according to certain laws, each one of which has its own individual dynamics, so, every child becomes a unique human being. Children gradually collect information about themselves and the world around them. They receive feedback about themselves from people who take care of them - mainly their family, mother and father. Their positive responses support the child's feeling of being loved, worthy of interest, which has a positive effect on them.

Purpose: Family environment is likely to have the strongest impact on the child's behaviour. Educational procedures, family climate, relationships between parents, those between parents and the child, the degree and methods of satisfying the child's needs, moral values, and social ties of the family - they all affect the child's behaviour.

Methods: In the presented paper, traditional desk research methods were used.

Conclusions: Behaviour is learned and has its purpose. Family teaches the child many things, e.g. how to cope with simple tasks, as well as about complex social inclusion.
\end{abstract}

Key words: child education, marriage, family, family education, the role of mothers, the role of fathers.

\section{Introduction}

Young people do not want to get married. According to a recent survey by the International Centre for Family and Work Studies (Lajdová, 2006), nearly one in five of young persons, graduates from various types of schools, considers partner cohabitation as an informal union of two people. One of the most common responses of young people is: "Once we have our own home, sufficient income and will enjoy our freedom, then we can start a family". Although it might seem that the so-called, cohabitation serves as good training for marriage, marriage counsellors claim that they do not have good experiences with such a form of living together as young people get used to a certain way of functioning, which is then difficult to change during marriage. The biggest changes in cohabitation occur when a baby is born. New responsibilities which cannot be postponed start occurring and the changes in how the couple functions tend to be more difficult to cope with for men than women. For them, cohabitation is a more comfortable form of living together.

Jaroslav Oberuč, DTI University, Dubnica nad Váhom, Slovakia; oberuc@dti.sk

Ladislav Zapletal, DTI University, Dubnica nad Váhom, Slovakia; zapletal@dti.sk 


\section{Acta Educationis Generalis \\ volume 7, 2017, issue 2}

According to experts, however, there must be a distinction drawn between long-term cohabitation and living together for few months before the wedding, when the mutual adaptation issues are being solved. The latter case is not harmful to the relationship. Such a form of cohabitation can help uncover an unsuitable partner for marriage, e.g. a tyrant, a jealous partner, or an asocial person. However, this is beneficial only if the partners do not fall for the illusion that marriage will change the other person for better.

Among professionals, twelve months are considered the optimum time of dating and getting to know each other. After this time, the level of endorphins is gradually dropping and a "crush" in the relationship enters a new phase. This is the time when partners should say what they want - they should either get married or break up. However, young people often live together for years and nothing happens. Such testing of living together is just dating. Even though, in recent years, the number of marriages has decreased almost by half per thousand inhabitants, marriage is not a doomed institution. In surveys, only six percent of Slovaks consider it outdated. Nevertheless, as young people who live together claim that there is no reason to enter a formal relationship when the life "without a piece of paper" provides more pleasant things as marriage - time spent together, the option of leaving anytime and sexual life.

In western Europe, cohabitation is widespread among young couples. In Sweden, for example, only 17 percent of new couples get married. In Slovakia, according to a survey by Focus realized eight years ago, cohabitation before marriage was approved by 47 percent of respondents while 48 percent disapproved. The number of people approving sexual intercourse before marriage, however, is much higher, up to 70 percent. Sociologists justify that cohabitation without marriage, unlike occasional sex, is seen as something more binding and more visible.

Although the society's approach to marriage has not changed significantly, the opinions on the age at which it is optimal to get married has been changing. In the past, there was a social pressure placed on people to get married young, even though it was clear that it produced unstable marriages leading to their failure. Today, the social pressure is not so strong.

\section{Marriage - the perfect arrangement or an old fashioned one?}

What are people's views on marriage? Opinions of those who have not tried it differ from those who can be considered veteran spouses. Nowadays, it may seem that its purpose is disappearing and, especially among young people, its importance has declined. The fact is that particularly young people postpone marriage for various reasons. Many young couples choose an alternative form of living together, so to speak "without a piece of paper".

The way of life and trends differ from generation to generation. Once, "ordinary" dating was not at all considered common. People married after a relatively short time. Walking the streets holding hands or in an embrace was almost unacceptable. And not so long ago, a twenty-year single woman was already considered a spinster. Today, it is different. Basically, everything has changed. People today spend more time studying and committing to work and their career, they enjoy their adult lives and they put off marital affairs for later.

If you ask a young woman who is in a long-term relationship when the wedding is going to take place, the most common answer you get is - "Don't be ridiculous". "And for 


\section{Acta Educationis Generalis \\ volume 7, 2017, issue 2}

what reason?" "If I want to live with someone, I do not need a piece of paper for it." (Vladuch, 2016).

It seems that marriage means the end of love itself and the beginning of duties, an inevitable stereotype and monotony. Before the marriage, the opinions on the institution of marriage are often influenced by the role models in the individual's environments, especially by our parents' relationships. Of course, arguments and days that strikingly resemble each other will come, but the purpose of marriage is much deeper. A married couple is the basic unit of the society. Love cannot be just dreamed, it is the most beautiful and precious thing. It is amazing to experience the moments of being together and it is extremely important to have someone close when problems come. And, of course, a harmonious family environment represents the basic precondition for bringing up children.

We firmly believe that the majority of people were lucky enough to grow up in a family where the parents manifested their love, where their shared kisses and hugs were a part of everyday reality and not only a memory from years ago. For some people, marriage is a loving reality while for others, it is a big mystery. The truth remains that, so far, no one has come up with a better form of the coexistence of two persons.

The notion of marriage can be defined as the relationship between two people (usually understood as an intimate and sexual relationship), which has a national, social, or religious recognition. It is created through contracts, civil or religious ceremonies.

In Slovakia, marriage is defined in the Act No. 36/2005 on Family and on Amendment of some other acts. Its basic principles include (Act no. 36/2005 Coll., Art. 1-4 and § 1$3)$ :

Marriage is a permanent community of a man and a woman. The society protects this commitment and promotes its welfare. Husband and wife are equal in rights and obligations. The main purpose of marriage is the foundation of a family and proper upbringing of children.

- A family based on marriage is the basic cell of society. All forms of families are broadly protected by the society.

- Parenting is a highly recognised mission of men and women by the society; and a stable family including the child's mother and father is the most suitable environment for the general and harmonious development of a child. The society provides parenthood not only with protection, but also with necessary care, especially in the form of material support and help.

- All family members have an obligation to help each other and, according to their ability and a capacity, to contribute to increasing the material and cultural level of the family. Parents have the right to raise their children in agreement with their own religious and philosophical opinions and the obligation to provide a peaceful and safe family environment. Parental responsibility is shared by both parents.

- A marriage is entered on the basis of free will and completing a consenting declaration of a man and a woman, after fulfilling the conditions specified by this law.

- The purpose of marriage lies in the foundation of a family and proper upbringing of children.

- Men and women who want to enter into marriage should first know each other's qualities and health condition. 


\section{Acta Educationis Generalis \\ volume 7, 2017, issue 2}

- The declaration of marriage is done in front of a municipal officer charged with keeping of the register, eventually an authority that fulfils the task, the register officer, or an authority of the church or a religious institution entitled thereto by a special regulation.

From the reference on the cited Family Act we cannot share the views of some of our citizens who seek to promote marriage as a union of two, adult, mentally capable persons, and does not insist that they must be of the opposite sex. Although gay marriages are legal in Canada, Spain, Portugal, France, Benelux and in most states in the USA, in Slovakia, according to the law, marriage is a union of a man and a woman, so this type of marriage is legally impossible.

There are ongoing discussions on the context of the status of marriage. According to the Slovak Constitution, marriage is a permanent union of a man and a woman. We can find it in all eras and in all cultures and that is because it meets the basic needs of humans incomparably better than any other institution, even though, over the centuries, it has undergone numerous changes in different cultures, social structures and spiritual attitudes. When considering these differences, permanent characteristics of mutual emotional relationships between men and women should not be forgotten. Although the dignity of this institution is not manifested everywhere with the same clarity, there is a sense of the greatness of marriage in all cultures, because the welfare of mankind and of human and Christian society is closely related to the favourable status of marital and family community. The ideal conditions for getting married are the presence of love, mutual understanding, as well as material support.

This is also demonstrated in the empirical research by Lucie Droppová (2006), in the work The Meaning of Marriage for the Formation of Families, where most of the married respondents indicated the main reason for entering into marriage the feelings of stability, security and safety in the partnership, as well as communication as a basis of marital understanding. As the main cause of staying single, people who are economically independent, stated the reason that, so far, they have not found a suitable partner.

\section{Family and upbringing in the family}

The concept of family is closely connected with the concept of marriage. However, a married couple becomes a family only if they meet the important function of the reproduction of humans. Family is a biosocial group, formed by at least one parent and a child. It is a small social group, made up of individuals connected by marriage, biological relations or adoption. Family members follow steady behaviour patterns, each family member fulfils a certain social role.

Průcha, Walterová and Mareš (1995, p. 189) consider family "The oldest social institution that performs the socializing, economic, social-regulatory, reproductive and additional functions. It creates a certain emotional climate, forms interpersonal relationships, values and attitudes, ethical principles and lifestyle. From the sociological point of view, it is the inclusion of individuals to social structures."

Due to these facts, Tamášová recommends understanding the concept of family as a "Small social group that forms a certain social system and from which its members get their identity. People living in it are characterized by their interconnected relationships emerging from partnership - marriage and kinship - parents and children" (Tamášová, 2007, p. 11). 


\section{Acta Educationis Generalis \\ volume 7, 2017, issue 2}

A family, as the primary social group, is characterized by intimacy, high unity, emotionality and authenticity, which are based on strong emotional bonds. Typically, it is the first social group that individuals come into contact with and, for some time, it is the only one. Most people were born into a family and lived in it for the most of their childhood and youth. Relationships between parents very actively influence the psyche of the child, the attitude which the child develops towards its surroundings. A quiet family environment is the first presupposition for enabling children to grow up into balanced and satisfied adults.

At present, the family performs the following functions (to compare: Hlásna, Horváthová, Mucha, \& Tóthová, 2006; Oberuč, Ušiak, \& Sláviková, 2014, p. 75; Krajčová \& Pasternáková, 2009):

1. Biological - in the sense of reproduction of people and regulation of sexual life. In a civilized society, it also includes conscious family planning, which is based on knowledge of genetics, biology and psychology. The developmental uniqueness of personality represents a specific area (Gáborová \& Porubčanová, 2016).

2. Economic - it is the share of individual family members on social production and consumption, which is meant to satisfy the needs of the family members. Each family has its own budget which depends on the income of the family members.

3. Social and educational - its task is introducing children into the society and their education. Its mission is to promote mental and physical development. Parental care gives children a sense of security and satisfaction, helping them to create and develop relationships with people and themselves. Porubčanová (2015) draws attention to the social partnership of parents and their participation when dealing with educational institutions.

4. Cultural and psychological (emotional) - this function lies in the fact that a family creates patterns of social coexistence for its members while providing them with an opportunity of emotional enjoyment, relaxation and practicing hobbies. Emotional relationships in the family are important for its stability, morality and civilized behaviour.

5. Protection - parents are obliged to look after the mental and physical development of their children, their nutrition, housing, clothing and, especially, to protect them from negative social-pathological phenomena. Emotional ties between spouses and between parents and children, as well as family ties provide the best conditions for happiness and are essential for the stability of a family. Pasternáková (2005) also stresses empathy in family relationships.

6. Rest and recovering - are focused on the application and development of children and other family members' interests in a reasonable and satisfactory manner, organization and efficient use of free time by children and on mental recovering of all family members.

7. Diagnostic - this function's task in the family is to analyse, recognise and identify the needs of the child by their parents and to implement these needs in accordance with their developmental needs (Labašová \& Porubčanová, 2012).

Fulfilling of the functions of the family directly depends on the relationship between the spouses, which is reflected in the relationship between parents and children. A cold or even hostile, or a completely ruined relationship between spouses does not provide the right conditions for the child's emotional development. 


\section{Acta Educationis Generalis \\ volume 7, 2017, issue 2}

The natural composition of complete families is represented by spouses - a father and a mother - and their offspring. It creates the optimal conditions for the completion of all family functions (Krajčírová \& Mikloško, 2004).

A family is therefore a unit, in which the mutual relationships of all its members are important. Some of the parents' roles can be substituted, e.g. where the mother is missing, the role can be replaced by the father and vice versa. In certain situations, however, the roles of a father and a mother are irreplaceable. A woman - mother - has a role that can never be replaced by men, while men have roles that cannot be replaced by anyone else. A man and a woman, as a father and a mother, need each other and complement each other, thus form a whole. Therefore, it is important that the family is complete and that there are both parents present as people whom the child needs.

\section{The role of the mother in the family}

The differences between men and women are biological. The question of which sex is more valuable seems unnecessary for the child's upbringing. Currently, there is much talk about the fading gender roles, but the collaboration of the mother and the father in the family is very important. Relationships between parents very profoundly affect the psyche of the child, the attitude that the child develops towards its surroundings.

Despite this finding, mothers have taken a central position in the family for many generations and are seen as the unifying figures or strengthening agents. The role of a mother is associated with the emotional and educational aspects and being exposed to various requirements and demands. A mother fulfils one of the most important social roles. She unconditionally loves her children, regardless of their beauty, skills or talents. Children, who have not experienced their mothers' love and tenderness, lose the most valuable and the most beautiful thing one could experience in childhood and which they emotionally recall in adulthood. The relationship between the mother and the child is of a particular importance in building emotional relationships that will help them find their place in the human society. It is very important that the child receives as many pleasant inputs at an early age (caress, smile and understanding) as possible. It is known that the shortage of these is reflected in latter aggression or inaccurate adaptation of a young person to social regulations.

Experts agree that children who could not grow up in the care of their mother, especially at pre-school age, when the emotional development is the most intense, are disadvantaged.

Mothers should also represent the aesthetic element in the family. This differs from the role of fathers, who are associated rather with artistic nature.

The aesthetic role of the mother in the family is mainly reflected in the overall climate, quietness, appearance of the home and in the behaviour of individual family members. It is precisely this climate that only women can create. The mother of the child embodies security, satisfaction, happiness, empathy towards the other person, towards their joys and sorrows. She does not cause unnecessary quarrels and does not underestimate other people's work. She is brave, able to cheer at the right moment, even if she herself may be in a difficult situation.

The contact between the mother and the child at an early age can create favourable conditions for the positive development of the child's personality. School-age children are already able to understand that it is necessary to be separated from the mother for some time; they are adequately prepared for this. 


\section{Acta Educationis Generalis \\ volume 7, 2017, issue 2}

The role of mothers is crucial in education because the foundations for the formation of human nature and character are laid long before people begin to use their brains, long before they learn how to speak with other people.

The correct implementation of the role of the mother in the family requires mental and physical maturity in order to be able to handle complex tasks associated with the function of a good mother and also performing all tasks and activities associated with the role of the father because, today, these two roles can be substituted almost to their full extent.

\section{The role of the father in the family}

The father and the mother are the first role models for children. They are consciously and unknowingly trying to imitate them. Therefore, it is necessary for both parents to deliver an optimal, quiet family climate as the basis for a peaceful, healthy development of their children (Kačáni \& Višňovský, 2005, p. 21).

The father should not only show love, but he should also be supportive to his wife. The father is a guarantee of security. The role of the father affects the relationship between the father and the mother as well. The role of the mother is linked to her emotional balance. This balance can be either strengthened or weakened, depending on what the mother's relationship with her husband looks like. Therefore, every mother's emotional change has a direct impact on the mother - child relationship. Therefore, a harmonious marriage is necessary for the proper emotional development of a child. Moreover, children perceive and create an image of their fathers not only based on their own observations, but also through their mothers' perception of their husbands. Therefore, a woman who despises her husband and discredits him in the eyes of children, helps to create a distinctive image of the father which, in turn, will also affect his role.

The father's educational function is mainly characterized by support and protection from the outside world, leading children to discipline, promoting their independence, autonomy and quality performance. Fathers should represent an authority, but it shall not take the form of authoritarianism, despotism or tyranny.

The father's is the male role in the family. He helps his son in accepting his manhood, including sexual orientation. In the case of daughters, fathers help them discover the role of mothers and women, and thus acquire the model of femininity. Women, who have not developed a close, friendly relationship with their fathers, do not feel comfortable among men and they do not understand them. Fathers should be committed to the life of their daughters. Fathers should have an understanding for their daughters' concerns; they should not send them to their mothers for advice.

Fathers' love should not be selfish, they should respect their children's personalities and, as they grow up, should become friends with them and help them become independent. Fathers should be those who children can rely on, authorities which can persuade, satisfy and effectively help them. They should be affectionate to the child, but this love must be fair, strict and demanding.

\section{Conclusion}

Family not only forms a social group, but its main function is to link people, as an expression of their interpersonal relationships, by which it becomes one of the most important parts of the system of human relationships. Family is an institution of 


\section{Acta Educationis Generalis \\ volume 7, 2017, issue 2}

socialization and development of a child's personality. A harmonious family environment represents not only an important basis for the child's present life, but it can positively affect their future as well. The quality of life of any society is directly dependent on the quality of family life (Rigová, 2005).

Babies are born helpless, unable to survive alone, so they need well-functioning families as an ideal group for their survival. Family is, in most cases, the first model of human coexistence, shaping the child's development and affecting their way of life. It provides children with support and, at the same time, it teaches them how to build their own individualities.

\section{References}

Droppová, L. (2006). Vietnam Mandelstam pre vznik rodiny. Retrieved from http://www.luciadroppova.eu/index.php?option=com_content\&task=view\&id=88\& Itemid $=33$

Duricová, L. (2005). Spôsob výchovy v rodine a formovanie osobnosti diet'at'a. In Rodinné prostredie ako factor socializácie a personalizácie osobnosti diet'at'a. Zborník čiastkových výstupov a riešení vedecko-výskumnej úlohy VEGA 1/0244/03. Banská Bystrica: Univerzita Mateja Bela, FHV.

Gáborová, L., \& Porubčanová, D. (2016). Vybrané kapitoly vývinovej psychológie. Brno: Tribun.

Hlásna, S., Horváthová, K., Mucha, M., \& Tóthová, R. (2006). Úvod do pedagogiky. Bratislava: ENIGMA.

Kačáni, V., \& Višňovský, L. (2005). Psychológia a pedagogika pomáhajú škole. Bratislava: IRIS.

Krajčírová, M., \& Mikloško, J. (2004). Mamy bocian nenosí. Bratislava: Motýl'.

Krajčová, N., \& Pasternáková, L. (2009). Štýly výchovy v rodine v kontexte s hodnotovou orientáciou detí. Prešov: Prešovská univerzita v Prešove.

Labašová, E., \& Porubčanová, D. (2012). Pedagogická diagnostika. Dubnica nad Váhom: DTI.

Lajdová, Z. (2006). Mladým sa do manželstva nechce. Prečo? Retrieved from http://koktail.pravda.sk/sexi-soubiznis/clanok/51324-mladym-sa-do-manzelstvanechce-preco/

Oberuč, J., Ušiak, G., \& Sláviková, G. (2014). Základy pedagogiky. Dubnica nad Váhom: Dubnický technologický inštitút v Dubnici nad Váhom.

Pasternáková, L. (2005). Hovoríme o empatii. Vychovávatel', Educatio, 51(9).

Porubčanová, D. (2015). Stratégie kooperácie relevantných inštitúcií pri eliminácii agresie žiakov. In J. Hanuliaková et al., Klíma školy a agresivita žiakov v empirickom kontexte (pp. 105-149). Dubnica nad Váhom: DTI.

Průcha, J., Walterová, E., \& Mareš, J. (1995). Pedagogický slovník. Praha: PORTÁL.

Tamášová, V. (2007). Teória a prax rodinnej edukácie. Ivánka pri Dunaji: AXIMA.

Ústava Slovenskej republiky a ústavné zákony. (2006). Žilina: PORADCA, s.r.o.

Vladuch. (2016). Manželstvo - najdokonalejší zväzok, či prežitok? Retrieved from http://zena.atlas.sk/manzelstvo-najdokonalejsi-zvazok-ci-prezitok/rodina/ manzelstvo/501992.html

Zákon č. 36/2005 Z. z. o rodine a o zmene a doplnení niektorých zákonov. Retrieved from http://www.zakonypreludi.sk/zz/2005-36 